\title{
CHARACTERISTICS AND ALOPECIA ACTIVITY OF PAKIS GAJAH (ANGIOPTERIS EVECTA (G.FORST) HOFFM.) GROWING IN GALUNGGUNG MOUNTAINSIDE, WEST JAVA
}

\author{
RESMI MUSTARICHIE ${ }^{1 *}$, DANNI RAMDHANI ${ }^{1}$, YOPIE ISKANDAR $^{2}$
}

${ }^{1}$ Department of Pharmaceutical Analysis and Medicinal Chemistry, Faculty of Pharmacy, Universitas Padjadjaran, Indonesia. ${ }^{2}$ Department of Biological Pharmacy, Faculty of Pharmacy, Universitas Padjadjaran, Indonesia. Email: resmi.mustarichie@unpad.ac.id

Received: 06 July 2017, Revised and Accepted: 08 August 2017

\section{ABSTRACT}

Objective: This study aims to determine characteristics and alopecia activity of Pakis Gajah (Angiopteris evecta (G.Forst) Hoffm.) growing in Galunggung mountainside, West Java.

Methods: A. evecta was collected, determined and extracted using ethanol 95\% by maceration. The extract was characterized based on Farmakope Indonesia method. Phytochemical screening was applied based on Farnsworth's method. Its alopecia activity was determined by Tanaka method on male Angora rabbits.

Results: The results showed that $A$. evecta simplicia had dried shrinkage characteristics of 3.35\%; ash content 4.73\%; water soluble sari content 20.11\%; ethanol soluble concentration 5.94\%; density 0.820 ; $\mathrm{pH}$ of extract 5.33; microchemical examination with $\mathrm{H}_{2} \mathrm{SO}_{4}$ gives a dark brown color, with $2 \mathrm{~N} \mathrm{NaOH}$ giving a bright yellow color, with the alkaline solution giving fluorescence, with $\mathrm{FeCl}_{3}$ giving a greenish-green color; its chemical contents were polyphenols, flavonoid, steroids, triterpenoids, quinones, monoterpenoid, and sesquiterpenoids. Alopecia activity showed that the water fraction and n-hexane had hair growth stimulating activity and water fraction was the fraction that had the most excellent activity, while ethyl acetate did not have such activities. The alopecia results were compared with minoxidil standards.

Conclusion: These results indicated that the water fractions A. evecta had the most alopecia activity on research animal. Our results suggest before it can be used in humans, it is necessary to do further research on the bald volunteers.

Keywords: Pakis gajah, Angiopteris evecta, Alopecia, Extract characteristics, Tanaka method.

(C) 2017 The Authors. Published by Innovare Academic Sciences Pvt Ltd. This is an open access article under the CC BY license (http://creativecommons. org/licenses/by/4. 0/) DOI: http://dx.doi.org/10.22159/ajpcr.2017.v10i11.21157

\section{INTRODUCTION}

Baldness or alopecia or abnormal hair growth is one of the problems often experienced by humans. Many factors either internal or external factors including hormonal disorders, side effects of medication, food intake, and stress are a factor causing this problem. Various methods are used to maintain the fertility and health of hair and minimalize and prevent hair problems. Health care for the hair can be done by way of cleaning your hair regularly and wear hair growth [1-3].

Traditional medicinal plants that have been widely recognized in the Indonesian community as an efficacious bald treatment include coconut, olive oil, ginkgo biloba, and hazelnut seeds. Some of them have been scientifically reported. These include the mixture of kemiri (Aleurites moluccana) and soybean (glycine max) extracts, seledri (Apium graveolens) extract, daun pare (Momordica charantia) ethanol extract, mangkokan (Nothopanax scutellarium) leaves extract, kacang panjang (Vigna sinensis) leaves extract, and green tea (Camellia sinensis) ethanol extract [4-6]. One of the plants that have not been recognized by the public and has long been proven for generations by the community at the foot of the Galunggung mountainside was a plant called Paku/Pakis Gajah or Paku/Pakis Munding (Sundanese) (Angiopteris evecta). Arnida et al. [7], reported in vitro antiplasmodial activity of ethanol extract of Borneo's A. evecta. The current plant studied thrives in the mountain slopes and foothills of Galunggung and had been recognized by the people around Mount Galunggung can prevent and treat baldness effectively especially for children who are bald because of high fever. Our previous article [5] reported activity of the Pakis Gajah but mentioned only ethanol and water extract. This paper reports on the effectiveness of the anti-baldness Paku Gajah using modified Tanaka et al. method [8] using types of Angora rabbit as well as its secondary metabolite from Paku Gajah extract and its fraction as well as determining the characteristic of the Paku Gajah extract based on Indonesian Pharmacopoeia [9].

\section{METHODS}

Plant sample

Paku Gajah (A. evecta) was collected from Galunggung mountainside and then determined in Taxonomy Laboratory, Department of Biology, Faculty of Mathematics and Natural Sciences, Universitas Padjadjaran, Indonesia.

\section{Rabbit}

Experimental animals used were male, white rabbit Angora strain, 4-5 months old, obtained from the Faculty of Animal Husbandry, Universitas Padjadjaran, Bandung. Ethical approval was applied to the Kementerian Riset, Teknologi dan Pendidikan Tinggi, Fakultas Kedokteran Universitas Padjadjaran, Komisi Etik.

\section{Extraction method}

Extraction methods used in this research was the maceration method guided by Farmakope Herbal Indonesia [10] and modified Gatbonton et al. [11] and Marnoto et al. [12] methods. A rotary evaporator and freeze dryer were used to concentrate the extract.

\section{Characterization of the extract}

The characterization of the extract referred to Pharmacopoeia Indonesia Edition 4 [9] includes the following:

1. Macroscopic examination was performed on the fresh root of the Pakis Gajah's simplicia, including the examination of its shape, color, taste, and smell 
2. Microscopic examination was performed on the simplicia powder using a microscope equipped with a camera (Olympus)

3. Determination of drying decrease was carried out in a heating kiln at $100-150^{\circ} \mathrm{C}$ for $5 \mathrm{hrs}$ or until a fixed weight was obtained on two consecutive weights after $1 \mathrm{hr}$ of intermittent heating

4. Determination of ash content was done by grinding with a gradual heating until it reached the temperature of $800-900^{\circ} \mathrm{C}$. The annealing was done until no more visible carbon remains, then repeated several times until the weight was constant

5. Determination of water-soluble content was carried by maceration for $24 \mathrm{hrs}$ with $100 \mathrm{~mL}$ of water-chloroform using the Erlenmeyer flask while repeatedly shaken for the first $6 \mathrm{hrs}$ and then stand for $18 \mathrm{hrs}$. The $20 \mathrm{~mL}$ filtrate was evaporated to dryness in a tared vapor plate. The rest is heated at a temperature of $105^{\circ} \mathrm{C}$ to a fixed weight

6. Determination of ethanol soluble content was determined by carefully weighing the simplicia powder, then heated for $24 \mathrm{hrs}$ with $100 \mathrm{~mL}$ of ethanol, using a clogged flask while repeatedly shaken for the first $6 \mathrm{hrs}$ and then left for $18 \mathrm{hrs}$. Strain quickly by avoiding ethanol evaporation. A total of $20 \mathrm{~mL}$ of filtrate was evaporated on the vapor plate that had been tilled until dry. The rest is heated at a temperature of $105^{\circ} \mathrm{C}$ to a fixed weight

7. Determination of extract density was determined against the crude extract $(5 \% \mathrm{w} / \mathrm{v})$ by the pycnometer

8. Determination of $\mathrm{pH}$ extract was made on extract $(5 \% \mathrm{w} / \mathrm{v})$ with $\mathrm{pH}-$ meter. The measurement temperature was recorded

9. Microchemical examination was done by reacting the powder of simplicia with a chemical reagent, among others: Concentrated $\mathrm{H}_{2} \mathrm{SO}_{4}$, $\mathrm{H}_{2} \mathrm{SO}_{4} 2 \mathrm{~N}$, concentrated $\mathrm{HNO} 3,2 \mathrm{~N} \mathrm{HNO}$, concentrated $\mathrm{HCl}, 2 \mathrm{~N} \mathrm{HCl}$, $\mathrm{NaOH} 2 \mathrm{~N}$, and concentrated $\mathrm{NH}_{4} \mathrm{OH}, \mathrm{NH}_{4} \mathrm{OH} 2 \mathrm{~N}, \mathrm{KI}, \mathrm{FeCl}_{3}$. Then seen under ultraviolet light and the fluorescence, color changes occurring were recorded.

\section{Phytochemical screening}

The phytochemical screening test was done to check the content of alkaloids, polyphenol, tannins, flavonoids, monoterpenoids, sesquiterpenoids, steroids, triterpenoids, quinones, and saponins in the sample based on Farnsworth method [13].

\section{Testing activities fertilizing hair}

Modification of Tanaka et al. [8] method was applied to test the activity of hair growth for ethanol and water extracts of Paku Gajah.

\section{Preparation of animal test}

Male rabbit acclimatized for 7 days and on day 6 before testing the hair growth stimulating activity, backs up cleanly shaven hair [8]. Then, ethanol $70 \%$ was applied to the back of the rabbit as an antiseptic and rested for $24 \mathrm{hrs}$. Backs shaven male rabbits were divided into five sections, each rectangular $2 \mathrm{~cm} \times 2 \mathrm{~cm}$ with a distance of $1 \mathrm{~cm}$ materials that will be tested on the backs of rabbits were:

a. Section 1: Negative control (i.e., a carrier material Na carboxymethyl cellulose [CMC])

b. Section 2: Positive control (minoxidil 2\%)

c. Section 3: Test material 1 (n-hexane fraction 20\%)

d. Section 4: Test material 2 (ethyl acetate fraction 20\%)

e. Section 5: Test material 2 (water fraction 20\%).

Basting ingredients in each section performed each twice a day, morning and evening as much as $1 \mathrm{~mL}$. Rabbit hair long observation conducted for 14 days, where the first day of the application of the test material was considered day 0 and this observation was done every 2 days by taking three strands of the longest hair in each section. Observed rabbit hair, straightened on a horizontal plane, and then attached using tape and measured using calipers.

\section{Data analysis}

Having obtained the rabbit hair length data per 2 days of research, the data were averaged and then statistically processed using the method of analysis of variance (ANOVA).

\section{RESULTS AND DISCUSSION}

\section{Characteristic examinations}

Macroscopic

Fresh A. evecta root: Dark brown, odorless, and elephant/cow foot shape. The flesh was white and fibrous. Simplicia: Brown and distinctive smell.

\section{Microscopic}

Microscopic examination results showed the presence of starch, parenchyma, vascular bundle, and cork tissue (Fig. 1).

It was found average from three examinations of dried shrinkage characteristics was $3.35 \%$; ash content $4.73 \%$; water-soluble content $20.11 \%$; ethanol soluble concentration $5.94 \%$; density 0.820 at $27.5^{\circ} \mathrm{C}$; $\mathrm{pH}$ of extract 5.33 at $26.4-26.7^{\circ} \mathrm{C}$; microchemical examination with $\mathrm{H}_{2} \mathrm{SO}_{4}$ gives a dark brown color, with $2 \mathrm{~N} \mathrm{NaOH}$ giving a bright yellow color, with the alkaline solution giving fluorescence, with $\mathrm{FeCl}_{3}$ giving a greenish-green color.

\section{Extraction}

Extraction was carried out by maceration with ethanol. Ethanol solvent selected as the liquid because ethanol was a universal solvent that can dissolve almost all of the secondary metabolites contained in Pakis Gajah and it was non-toxic and safe. With the ability to sum up the wide-ranging polarity nonpolar compounds that polar and precipitate proteins and inhibit the action of the enzyme so that it can avoid the hydrolysis and oxidation [14]. Other researchers such as Mismawati et al. [15], in their study on the antibacterial activity of $A$. evecta from East Kalimantan, using methanol as their extraction solvent. Gracelin et al. [16] using various solvent including petroleum ether, chloroform, benzene, methanol, and aqueous in their study on their antibacterial screening of $A$. evecta. Kale [17], however, using absolute ethanol in the phytochemical analysis of whole plant extracts of Angiopteris heliferiana. We thought methanol was good, but it was toxic.

\section{Phytochemical screening}

Table 1 is the result of phytochemical screening Paku Gajah root.

Miswati [15], Gracelin [16], and de Britto [18] reported that they found alkaloid in their screening results which were not detected in our result. We have tried it 3 times without finding alkaloid. It was not clear the reason of this, most likely due to a place where A. evecta growing.

The extract obtained from the maceration in the form of brown viscous extract and characteristic odor. While the yield of the extract obtained amounted to $11.05 \%$. Extract fractionation method used in this research
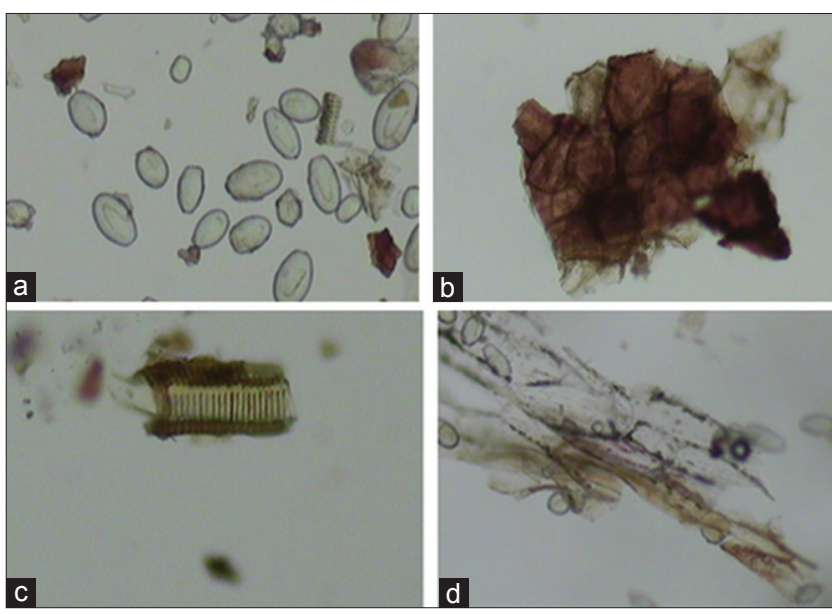

Fig. 1: Microscopic of Angiopteris evecta root, (a) starch, (b) parenchyma, (c) vascular bundle, and (d) cork tissue 
was a liquid-liquid extraction (LLE). The LLE was a method that holds the principle solves dissolve like where the separation process using two solvents which do not mix with each other so that a particular compound would be separated according to the suitability of the nature of the solvents [19]. The results of the LLE were the fraction of water, n-hexane, and ethyl acetate.

\section{Rabbit hair length measurement results}

The measurement of the rabbit hair growth can be seen in Table 2 and Fig. 2.

Based on Table 2 and Fig. 2, it was found that at the beginning of the measurement already seen the difference in the length of each section, although not too significant. After day 14 of testing, it was found that the hair on the part of the test material 3 (the water fraction $20 \%$ ) had results that the highest or nearly equivalent to the positive control (minoxidil) and exceeds the negative control ( $\mathrm{Na} \mathrm{CMC}$ ) was the average hair length $2.003 \mathrm{~cm}$. In the first test material (n-hexane fraction 20\%) was seen that the length of the hair together with hair long on the negative control that is an average of $1.573 \mathrm{~cm}$ hair length. While in the test material 2 (ethyl acetate fraction 20\%) shown that growth was far below the negative control negative, and seen that hair growth in the area had been suspended since the measurement day 4. Broadly speaking, it could be seen that the fraction of the most well to nourish hair growth was a fraction of the water. Mustarichie et al. [5] using the sample from Gunung Galunggung mentioned that both ethanol and water extract with the levels of $40 \%$ showed the best results cope with minoxidil.

Based on statistical analysis of the data obtained by the method ANOVA was not significant $(<0.05)$. ANOVA results had not indicated the extent

Table 1: Results of phytochemical screening of Paku Gajah root

\begin{tabular}{ll}
\hline Secondary metabolites & Results \\
\hline Alkaloids & - \\
Flavonoids & + \\
Saponin & + \\
Polyphenol & + \\
Tannin & + \\
Quinones & + \\
Monoterpene and sesquiterpene & + \\
Steroid dan terpenoid & - \\
\hline
\end{tabular}

+: Detected, -: Not detected to which differences were given, so did a further test. The further test used was the study Newman-Keuls. Based on studies Newman-Keuls obtained significant results $(>0.05)$, where there were differences in the activity of the rabbit hair growth fertilizer every fraction although not real. The fraction of water and n-hexane have hair growth stimulating activity while ethyl acetate had no such activity and water fraction was the fraction of activity that had best hair growth fertilizer.

The compounds contained in the fraction of water were a compound that was polar. Of the above compounds, compounds that affect the hair growth such as flavonoids, saponins, polyphenols, and tannins. Flavonoids have activity as a bactericide which could kill microorganisms that could damage the hair and cause hair loss and can accelerate hair growth. Saponin was a compound that would be able to form a foam that could cleanse the skin of impurities. In addition, saponins have activity as counterirritant that can improve peripheral blood circulation so as to improve hair growth [20]. Polyphenols have activity as anti-free radicals which can inhibit and reduce free radicals [21]. Free radicals can originate from outside the body (exogenous) or from the body (endogenous). One of the factors that can cause hair loss was free radicals. Therefore, the polyphenols contained in the Paku gajah root could inhibit free radical formation, and the hair growth maintained, while for tannins, it has properties that could bind and protect the proteins so that the proteins needed for hair growth could be maintained [22].

\section{CONCLUSION}

The results showed the water fraction, and n-hexane has hair growth stimulating activity, and water fraction was the fraction that had the most excellent activity, while ethyl acetate did not have such activities.

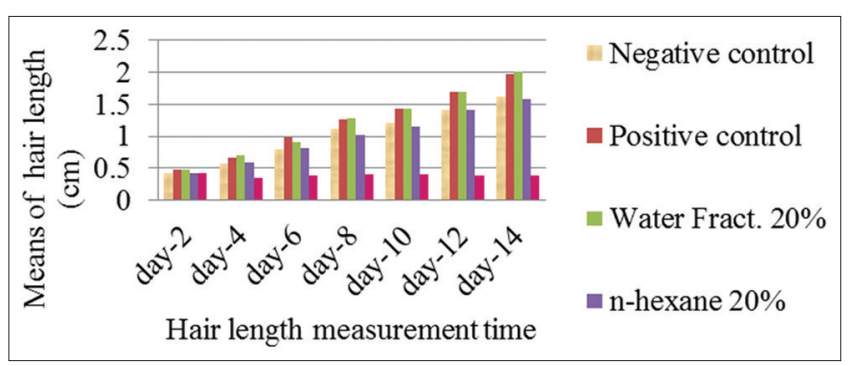

Fig. 2: Hair length by fractions

Table 2: Results of measurement rabbit hair growth

\begin{tabular}{|c|c|c|c|c|c|c|c|}
\hline \multirow[t]{2}{*}{ Preparation types } & \multicolumn{7}{|c|}{ Measurement (cm) rabbit hair on days of.... } \\
\hline & 2 & 4 & 6 & 8 & 10 & 12 & 14 \\
\hline \multirow[t]{3}{*}{ Negative control } & 0.400 & 0.540 & 0.750 & 1.110 & 1.220 & 1.420 & 1.590 \\
\hline & 0.420 & 0.515 & 0.820 & 1.115 & 1.200 & 1.430 & 1.620 \\
\hline & 0.430 & 0.680 & 0.800 & 1.105 & 1.190 & 1.415 & 1.630 \\
\hline Means & $0.417 \pm 0.015$ & $0.578 \pm 0.089$ & $0.790 \pm 0.036$ & $1.110 \pm 0.005$ & $1.203 \pm 0.015$ & $1.422 \pm 0.008$ & $1.613 \pm 0.020$ \\
\hline \multirow[t]{3}{*}{ Positive control } & 0.470 & 0.760 & 0.960 & 1.340 & 1.405 & 1.740 & 2.000 \\
\hline & 0.480 & 0.600 & 1.100 & 1.250 & 1.450 & 1.720 & 1.970 \\
\hline & 0.490 & 0.610 & 0.905 & 1.200 & 1.440 & 1.640 & 1.975 \\
\hline Means & $0.480 \pm 0.010$ & $0.657 \pm 0.090$ & $0.988 \pm 0.100$ & $1.263 \pm 0.070$ & $1.432 \pm 0.024$ & $1.700 \pm 0.053$ & $1.982 \pm 0.016$ \\
\hline \multirow{3}{*}{ Water fraction Fraksi 20\% } & 0.480 & 0.720 & 0.950 & 1.270 & 1.410 & 1.685 & 1.970 \\
\hline & 0.500 & 0.735 & 0.890 & 1.310 & 1.420 & 1.680 & 2.030 \\
\hline & 0.465 & 0.660 & 0.870 & 1.255 & 1.440 & 1.720 & 2.010 \\
\hline Means & $0.482 \pm 0.018$ & $0.705 \pm 0.040$ & $0.903 \pm 0.042$ & $1.278 \pm 0.028$ & $1.423 \pm 0.015$ & $1.695 \pm 0.022$ & $2.003 \pm 0.030$ \\
\hline \multirow[t]{3}{*}{ n-hexane fraction $20 \%$} & 0.430 & 0.600 & 0.830 & 1.000 & 1.200 & 1.435 & 1.590 \\
\hline & 0.400 & 0.570 & 0.810 & 1.095 & 1.150 & 1.400 & 1.600 \\
\hline & 0.410 & 0.610 & 0.830 & 0.970 & 1.110 & 1.420 & 1.530 \\
\hline \multirow{3}{*}{ Ethyl acetate fractions $20 \%$} & 0.420 & 0.360 & 0.370 & 0.430 & 0.410 & 0.400 & 0.401 \\
\hline & 0.450 & 0.355 & 0.400 & 0.410 & 0.360 & 0.410 & 0.420 \\
\hline & 0.410 & 0.340 & 0.380 & 0.355 & 0.415 & 0.370 & 0.360 \\
\hline Means & $0.427 \pm 0.020$ & $0.352 \pm 0.010$ & $0.383 \pm 0.015$ & $0.398 \pm 0.039$ & $0.395 \pm 0.030$ & $0.393 \pm 0.021$ & $0.394 \pm 0.031$ \\
\hline
\end{tabular}


Our results suggest before it can be used in humans, it is necessary to do further research on the bald volunteers.

\section{ACKNOWLEDGMENT}

We thank PUPT-DIKTI 2016 for financing this project.

\section{REFERENCES}

1. Dalimartha S, Soedibyo M. Hair Care with Medicinal Plants and Diet Supplements (Perawatan Rambut dengan Tumbuhan Obat dan Diet Suplemen). Bogor: PT. Penebar Swadaya; 1998. p. 14-8.

2. Stough D, Stenn K, Haber R, Parsley WM, Vogel JE, Whiting DA, et al. Psychological effect, pathophysiology, and management of androgenetic alopecia in men. Mayo Clin Proc 2005;80:1316-22.

3. Jain R, Monthakantirat $\mathrm{O}$, Tengamnuay $\mathrm{P}$, De-Eknamkul W. Identification of a new plant extract for androgenic alopecia treatment using a non-radioactive human hair dermal papilla cell-based assay. BMC Complement Altern Med 2016;16:18

4. Kuncari ES, Iskandarsyah I, Praptiwi P. Test irritation and activity of white rat hair growth: Apigenin gel and celery gel effect (Apium graveolens L.), Media Litbangkes 2015;25(1):15-22.

5. Mustarichie R, Indriyati W, Mukmin A, Ramdhani D. Activity of Angiopteris evecta for baldness treatment. J Chem Pharm Res 2016;8(5):821-30.

6. Amin J, Simamora EL, Anwar E, Djajadisastra J. Green tea (Camellia sinensis L.) ethanolic extract as hair tonic in nutraceutical: Physical stability, hair growth activity on rats, and safety test. Int J Pharm Pharm Sci 2014;6(5):94-9.

7. Arnida A, Wahyono W, Mustofa M, Asmahsusidarti R. In vitro antiplasmodial activity of ethanol extracts of Borneo medicinal plants (Hydrolea spinosa, Ampelocissus rubiginosa, Uraria Crinite, Angiopteris evecta. Int J Pharm Pharm Sci 2015;7(5):72-5.

8. Tanaka S, Saito M, Tabata M. Bioassay of crude drugs for hair growth promoting activity in mice by a new simple method. Planta Med 1980;40:84-90.

9. Depkes RI. Farmakope Indonesia. $4^{\text {th }}$ ed. Jakarta: Depkes, RI; 1995.

10. Departemen Kesehataan RI. Farmakope Herbal Indonesia. $1^{\text {st }}$ ed. Jakarta: Departemen Kesehataan RI; 2015. p. 17-8.

11. Gatbonton GL, de Jesus AP, Lorenzo KM, Uy MM. Soxhlet Extraction of Philippine Avocadro Fruit Pulp Variety 240, Presented at the Research Congress 2013 De La Salle University Manila March, 7-9; 2013.

12. Marnoto T, Haryono G, Gustinah D, Putra FA. Tannin extraction as a natural dye from the Putrimalu plant (Mimosa pudica) using organic solvent, Reaktor 2012;14(1):39-45.

13. Farnsworth NR. Biological and phytochemical screening of plants. J Pharm Sci 1966;55(3):225-76.

14. Harborne AJ. Phytochemical Methods a Guide to Modern Techniques of Plant Analysis, Metode Fitokimia Translated by Kosasih Padmawinata dan Iwang Soediro. Bandung: Penerbit ITB; 1987.

15. Mismawati A, Suwannaket CS, Mingvanish W, Kuspradini H, Kusuma IW, et al. Phytochemical Screening and Bioactivity of Angiopteris evecta leaves from East Kalimantan, Pure and Applied Chemistry International Conference 2015 (PACCON2015). Available from: https://www.researchgate.net/publication/286154161.

16. Gracelin DH, de Britto AJ, Kumar PB. Antibacterial screening of a few medicinal ferns against antibiotic resistant phyto pathogen. Int J Pharm Sci Res 2012;3(3):868-73

17. Kale MV. Phytochemical analysis of whole plant extracts of Angiopteris heliferiana. Res J Life Bioinform Pharm Chem Sci 2015;1(3):139-42.

18. de Britto AJ, Gracelin DH, Kumar PB. Study on potential biocontrol agent-Angiopteris evecta (Forst) Hoff. Against Xanthomonas campestris. Eur J Mol Biol Biochem 2014;1(5):192-5.

19. Koch J, Shiveler G. Design Principles for Liquid-Liquid Extraction, CEP Magazine; 2015. Available from: https://www.aiche.org/resources/ publications/cep/2015/november/design-principles-liquid-liquidextraction.

20. Marchaban JC, Soegihardjo S, Kumarawati FE. Test of Randu Leaf Activity (Ceiba pentandra Gaertn.) as a Hair Grower (Uji Aktifitas Daun Randu (Ceiba Pentandra Gaertn.) Sebagai Penumbuh Rambut, UGM, Yogyakarta; 2007. Available from: https://www.mot.farmasi. ugm.ac.id/files/41Daun\%20randu marchaban.pdf.

21. Robinson T. High Organic Plant Content (Kandungan Organik Tumbuhan Tinggi). Bandung: Penerbit ITB; 1995.

22. Sitompul S. Content of Polyphenol Compounds in Aloe Vera Plants, Mimba Leaves and Noni Fruit Dregs (Kandungan Senyawa Polifenol Dalam Tanaman Lidah Buaya, Daun Mimba dan Ampas Buah Mengkudu). Bogor: Prosiding Temu Teknis Fungsional Non Peneliti; 2002. p. $48-55$ 